\title{
PENGEMBANGAN PARIWISATA KABUPATEN PEMALANG BERBASIS GREEN TOURISM
}

\author{
Suzanna Ratih Sari*, Sukawi* \\ *)Departemen Arsitektur, Fakultas Teknik, Universitas Diponegoro
}

\begin{abstract}
Permasalahan saat ini yang dihadapi berbagai wilayah di Jawa Tengah adalah belum adanya dokumen yang dapat membantu mengarahkan suatu wilayah dalam rencana pemanfaatan, pengembangan maupun pengendalian dalam pemanfaatan wilayah. Sehingga banyak diantara wilayah-wilayah di Jawa Tengah yang melakukan kegiatan peningkatan kualitas wilayah tanpa adanya pedoman perencanaan yang dapat diacu/dijadikan sebagai referensi. Salah satu diantaranya adalah Kabupaten Pemalang yang hingga kini belum memiliki panduan atau acuan yang disepakati di tingkat daerah yang dapat memberikan arah yang jelas mengenai pola pengembangan khususnya pariwisata. Arahan tersebut dibutuhkan pada saat Kabupaten Pemalang berkeinginan untuk mengoptimalkan potensi pariwisata yang ada, baik dalam konteks regional (propinsi) maupun nasional, demi meningkatkan kesejahteraan masyarakat melalui sektor kepariwisataan.

Penelitian ini menggunakan metode deskriptif dan analitis terhadap urgensi dari upaya pengembangkan sektor pariwisata di Kabupaten Pemalang yang didasarkan pada rencana tata ruang wilayah (dalam hal ini RTRW Kabupaten Pemalang Tahun 2011-2031) yang telah ada. Dengan output penelitian berupa konsep strategi pengembangan pariwisata kabupaten pemalang berbasis green tourism.
\end{abstract}

Keywords: Kabupaten Pemalang, Pariwisata, Green Tourism

\section{Pendahuluan}

Penataan ruang sebagai proses perencanaan tata ruang, pemanfaatan ruang, dan pengendalian pemanfataan ruang merupakan salah satu kesatuan sistem yang tidak terpisahkan satu dengan yang lainnya. Rencana tata ruang disusun dengan perspektif menuju keadaan pada masa depan yang diharapkan, bertitik tolak dari data, informasi dan ilmu pengetahuan dan teknologi yang dapat dipakai, serta memperhatikan keragaman wawasan kegiatan tiap sektor, perkembangan masyarakat dan lingkungan hidup berlangsung secara dinamis, ilmu pengetahuan dan teknologi berkembang seiring dengan berjalannya waktu. Oleh karena itu, suatu wilayah memerlukan perencanaan yang bertujuan meningkatkan kualitas wilayah agar dapat dimanfaatkan dan dikendalikan pemanfaatannya untuk mencapai kondisi optimal yang di dalamnya mencakup semua aktivitas dalam ruang wilayah tersebut.

Permasalahan saat ini yang dihadapi berbagai wilayah di Jawa Tengah adalah belum adanya dokumen yang dapat membantu mengarahkan suatu wilayah dalam rencana pemanfaatan, pengembangan maupun pengendalian dalam pemanfaatan wilayah. Sehingga banyak diantara wilayah-wilayah di Jawa Tengah yang melakukan kegiatan peningkatan kualitas wilayah tanpa adanya pedoman perencanaan yang dapat diacu/dijadikan sebagai referensi. Salah satu diantaranya adalah Kabupaten Pemalang yang hingga kini belum memiliki panduan atau acuan yang disepakati di tingkat daerah yang dapat memberikan arah yang jelas mengenai pola pengembangan khususnya pariwisata. Arahan tersebut dibutuhkan pada saat Kabupaten Pemalang berkeinginan untuk mengoptimalkan potensi pariwisata yang ada, baik dalam konteks regional (propinsi) maupun nasional, demi meningkatkan kesejahteraan masyarakat melalui sektor kepariwisataan. Selama ini pengembangan kepariwisataan di Kabupaten Pemalang dapat dikatakan belum secara maksimal dapat memberikan dampak ganda kepada masyarakat. Beberapa daya tarik wisata bahkan belum dapat berkembang sesuai dengan harapan masyarakat bahkan tingkat kunjungan wisatawan ke Kabupaten Pemalang belum menunjukkan angka yang signifikan. Oleh Karena itu, guna mewujudkan tindakan penanganan yang terprogram terkait dengan arahan tersebut, maka kegiatan penyusunan Rencana Induk Pengembangan Pariwisata Kabupaten Pemalang menjadi memiliki nilai yang sangat penting. Diharapkan, dengan adanya Rencana Induk Pengembangan Pariwisata akan mampu mendongkrak kunjungan wisatawan serta mengarahkan pengembangan pariwisata Kabupaten Pemalang yang berkelanjutan. Dalam artian pengembangan pariwisata harus dapat memberikan keseimbangan antara pembangunan ekonomi, sosial budaya dan konservasi. 


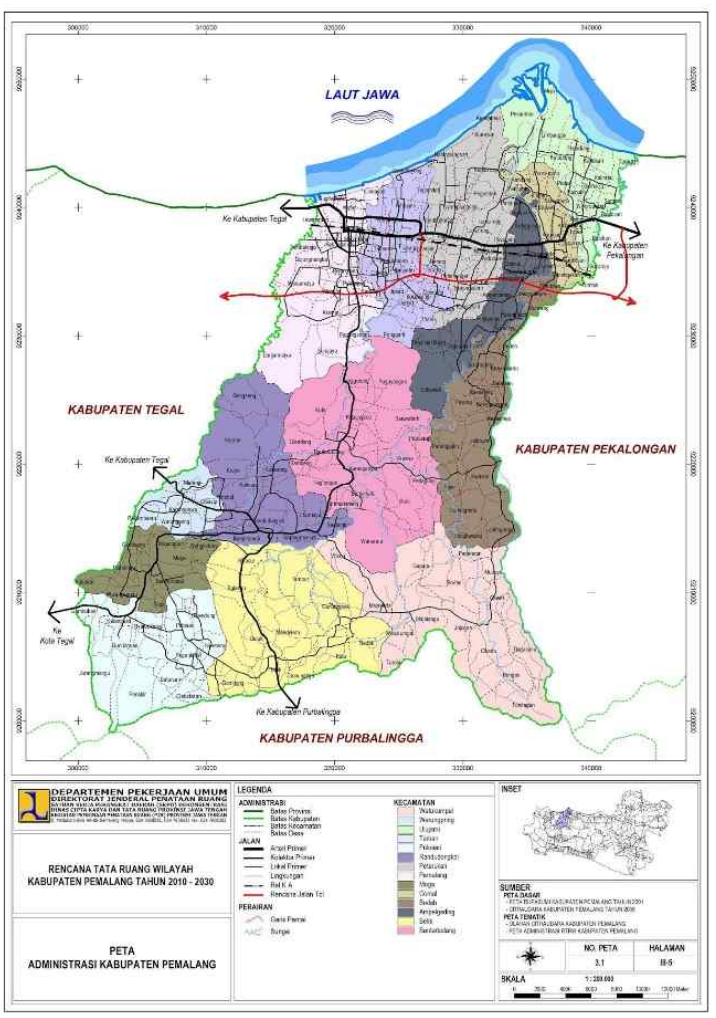

Gambar 1. Peta Kabupaten Pemalang (http://peta-kota.blogspot.co.id/2017/01/peta-kabupatenpemalang.html)

\section{Metode}

Penelitian ini menggunakan metode deskriptif dan analitis terhadap urgensi dari upaya pengembangan sektor pariwisata di Kabupaten Pemalang yang didasarkan pada rencana tata ruang wilayah (dalam hal ini RTRW Kabupaten Pemalang Tahun 2011-2031) yang telah ada. Proses penelitian dilakukan melalui beberapa tahapan, yakni:

- Pengumpulan data terkait dengan Potensi dan Daya Tarik Wisata serta permasalahan-permasalahan yang ada

- Analisis terhadap potensi eko wisata, Ketersediaan Sarana Dan Prasarana, Pengelolaan dan Kelembagaan, serta kendala-kendala pengembangan eko wisata kabupaten Pemalang

- Konsep dan strategi aksi pengembangan eko wisata di Kabupaten Pemalang berbasis "Green Tourism"

\section{Hasil Penelitian}

Pembangunan pariwisata dilaksanakan berdasarkan prinsip menjunjung tinggi nilai agama dan budaya, serta keseimbangan antara upaya pengembangan manajemen atraksi untuk menciptakan daya tarik wisata yang berkualitas, berdaya saing, serta mengembangkan upaya konservasi untuk menjaga kelestarian dan keberlanjutan sumber dayanya. Obyek daya tarik wisata diklasifikasikan menjadi 3, yakni wisata alam, wisata budaya dan wisata religi, serta wisata buatan. Wisata alam di Kabupaten Pemalang berupa wisata pantai, wisata tirta atau bahari (termasuk di dalamnya wisata laut, danau, sungai, air terjun atau curug), wisata pegunungan dan perbukitan, wisata perkebunan, dan lainnya. Wisata budaya berupa kesenian-kesenian daerah yang menunjang pengembangan wisata lain. Wisata religi merupakan bagian dari wisata budaya yakni berupa kompleks bangunan bersejarah, peninggalan kuno, wisata ziarah ke makam bersejarah, dan sebagainya. Sementara untuk wisata buatan di Kabupaten Pemalang berupa waterboom atau wahana permainan air, wahana permainan anak, dan sarana permainan penunjang obyek wisata seperti wahana outbond.

\section{Pembahasan}

Pengembangan pariwisata di suatu daerah selalu terkait dengan pengembangan tata ruang yang dilakukan. Secara tidak langsung, pengembangan yang terjadi pada sector pariwisata akan mempengaruhi pengembangan tata ruang wilayah secara umum. Begitupun sebaliknya, pengembangan tata ruang yang dilakukan secara menyeluruh tentu juga termasuk pada pengembangan sektor pariwisatanya. Dengan telah melakukan analisis pembobotan dan identifikasi SWOT, maka dapat ditentukan pengelompokan obyek wisata. Terdapat tiga kelompok jenis pengembangan obyek wisata, yakni obyek wisata unggulan, obyek wisata andalan, dan obyek wisata potensial.

Obyek wisata unggulan adalah kawasan obyek wisata langka, serta memiliki daya tarik yang kuat. Di samping itu, obyek wisata tersebut setidaknya memiliki keunikan tersendiri dan tidak ditemukan di daerah lain. Keberadaannya sudah teruji oleh pasar wisata domestik dan internasional yang mantap dan mampu memberikan pembangunan secara cepat dan menyeluruh bagi wilayah secara keseluruhan.

Obyek wisata andalan adalah kawasan obyek wisata dan daya tarik yang kuat, memiliki posisi kuat dalam lingkup regional serta pasar domestik dan mulai ditawarkan pada pasar internasional sehingga mempunyai kontribusi perekonomian.

Obyek wisata potensial adalah kawasan wisata dengan obyek wisata dan daya tarik wisata yang relatif baru berkembang namun diperkirakan mempunyai kekuatan produk yang cukup besar di masa datang meskipun jangakauan pasarnya adalah sebatas wisatawan domestik.

Penentuan klasifikasi atau pengelompokan obyek wisata tersebut juga dilihat dari tingkat kunjungan wisatanya. Dari hasil tersebut, dapat diklasifikasikan arahan pengembangan obyek wisata di Kabupaten Pemalang, yakni: 
- Obyek Wisata Unggulan

Pantai Widuri, Widuri Water Park, Obyek Wisata Andalan, Rainbow Rafting River Pemalang, Zatoobay Waterboom, Pantai Keramat Sari, Kolam Renang Moga, Kawasan Wisata Agro Semugih, Kawasan Wisata Agro Jambe Kembar, Pantai Joko Tingkir (Pantai Nyamplungsari), Pantai Kaliprau, Kawasan Wisata Telaga Silating, Kawasan Wisata Telaga Rengganis, Kawasan Wanawisata Cempaka Wulung, Kawasan Wisata Gardu Pandang Gunung Slamet

\section{- Obyek Wisata Potensial}

Kawasan Goa Gunung Wangi (Goa Pengantin, Goa Buyung, Goa Laren, Goa Bandung, Gua Siluman), Kawasan Wisata Gunung Gajah, Kawasan Wisata Bukit Mendelem, Goa Cilik, Goa Jepang, Watu Sewidak, Telaga Indah Gambuhan, Kawasan Wisata Curug Bengkawah, Kawasan Wisata Curug Barong, Kawasan Wisata Curug Lawang, Kawasan Wisata Curug Sibedil, Curug Cina, Curug Cikuwung, Pemandian Belanda, Kawasan Hutan Lindung Gunungsari, Desa Wisata Cikendung, Desa Wisata Mojo, Makam Syech Maulana Syamsudin, Makam Pangeran Benowo, Makam Syech Pandanjati, Makam Mbah Carum, Makam Mbah Buyut Sumber Agung, Makam Syech Jambu Karang, Komplek Pemakaman Among Jiwo, Makam Mbah Jurang Mangu, dan Komplek Pemakaman Bupati Pemalang.

\section{Konsep Pengembangan}

Pengembangan pariwisata harus direncanakan secara menyeluruh, sehingga dapat diperoleh manfaat yang optimal bagi masyarakat, baik dari segi ekonomi, sosial dan kultural. Perencanaan tersebut harus mengintegrasikan pengembangan pariwisata ke dalam suatu program pembangunan ekonomi, fisik, dan sosial dari suatu negara. Di samping itu, rencana tersebut harus mampu memberikan kerangka kerja kebijaksanaan pemerintah, untuk mendorong dan mengendalikan pengembangan pariwisata.

Pengembangan pariwisata diarahkan agar dapat membawa kesejahteraan ekonomi yang tersebar luas dalam masyarakat. Pengembangan pariwisata harus sadar lingkungan, sehingga pengembangannya mencerminkan ciri-ciri khas budaya dan lingkungan alam suatu negara, bukan merusak lingkungan alam dan budaya yang khas. Konsep pengembangan pariwisata akan mempertimbangkan beberapa hal, antara lain:

- Posisi daya tarik (Positioning)

- Sinergi daya tarik wisata

- Keselarasan antar sector

- Keselarasan lingkungan

Pertimbangan utama harus mendayagunakan pariwisata sebagai sarana untuk memelihara kekayaan budaya, lingkungan alam dan peninggalan sejarah
Pengembangan pariwisata harus diarahkan agar pertentangan sosial dapat dicegah seminimal mungkin, sedapat mungkin harus menampakkan perubahan perubahan sosial yang positif. Keseimbangan antara ekonomi, kehidupan dan alam diperlukan untuk:

- Meningkatkan pendapatan (standar hidup)

- Penggunaan sumberdaya yang efektif (energy saving, recycling, dan lain-lain)

- Menjaga dan memperkaya lingkungan

- Pengarahan amenitas (leisure, comfort, contact with nature, dan lain-lain)

Berdasarkan hal tersebut, beberapa pertimbangan yang perlu diperhatikan dalam perumusan konsep pengembangan kawasan wisata, adalah sebagai berikut:

- Perlunya pemisahan zoning antara kawasan wisata dan kegiatan lainnya. Tujuannya untuk menghindari kesalahan penafsiran dalam pelaksanaan rencana tata ruang di masa datang.

- Lahan yang saat ini mempunyai ikatan dengan kehidupan dan adat istiadat masyarakat setempat harus dipertahankan keberadaannya. Tujuannya untuk menghindari timbulnya benturan kepentingan antara pihak pelaksana pembangunan dengan masyarakat.

- Lahan yang ekologinya diperkirakan tidak stabil dan menimbulkan dampak bagi daerah sekitarnya atau lahan yang memerlukan kelestarian lingkungan dibebaskan dari peruntukan kegiatan pembangunan dan diusulkan sebagai kawasan konservasi dan preservasi. Tujuannya untuk mempertahankan keseimbangan ekologi di seluruh kawasan perencanaan.

Dalam pengembangan kawasan wisata sebaiknya digunakan teknik konservasi budaya, artinya melalui pengembangan pariwisata secara langsung dapat membantu pelestarian atau bahkan menghidupkan kembali musik dan tarian misalnya kerajinan tangan, pakaian daerah, upacara adat dan gaya arsitektur daerah yang hampir punah.

Konsep pengembangan kepariwisataan terkait dengan potensi dan permasalahan pengembangan kepariwisataan dan isu isu strategis pengembangan kepariwisataan yang dihadapi. Pengembangan kawasan wisata dilakukan secara bertahap sesuai perkembangan pasar dan keseimbangan masyarakatnya. Untuk mencapai optimalisasi pemanfaatan ruang sesuai dengan peranan dan fungsi yang diharapkan, batasan serta potensi yang terdapat di kawasan perencanaan, maka konsepsi pengembangannya sebagai kawasan wisata didasarkan pada kriteria-kriteria berikut:

- Kesesuaian lahan dan kemampuan lahan dalam mendukung pengembangan kawasan wisata;

- Kebutuhan ruang dan komponen dalam menampung perkembangan kegiatan pariwisata; 
- Tingkat kemudahan hubungan intensitas kegiatan dan kecenderungan perkembangan.

Aspek penting dalam tujuan pengembangan pariwisata Kabupaten Pemalang yang dirumuskan adalah aspek konsep keberlanjutan. Pariwisata berkelanjutan atau sustainable tourism adalah sebuah konsep turunan dari konsep pembangunan berkelanjutan yang ada pada laporan World Commission on Environment and Development, berjudul Our Common Future (atau lebih dikenal dengan the Brundtland Report) yang diserahkan ke lembaga PBB pada tahun 1987 (Mowforth dan Munt 1998). Pembangunan kepariwisataan yang berkelanjutan (Sustainable Tourism Development) adalah pembangunan keberlanjutan yang dicapai melalui kepariwisataan. Pembangunan berkelanjutan adalah pembangunan ekonomi yang berperspektif jangka panjang, yang menyeimbangkan manfaat pembangunan ekonomi dengan biaya lingkungan dan sosial. Pembangunan pariwisata yang berkelanjutan dicapai dengan menyeimbangkan ketiga elemen utama dalam pembangunan pariwisata yang berkelanjutan, yaitu lingkungan, ekonomi, dan sosial. Prinsip umum dalam sustainable tourism yaitu:

- Menyeimbangkan pemanfaatan lingkungan dengan manfaat ekonomis dari kepariwisataan.

- Menyeimbangkan pemanfaatan sumberdaya lingkungan dengan perubahan nilai sosial dan komunitas yang disebabkan oleh penggungaan sumberdaya lingkungan, dan

- Menyeimbangkan pertumbuhan ekonomi dan dampak pertumbuhan ekonomi pada nilai sosial dan komunitas.

Hal tersebut hanya dapat terlaksana dengan sistem penyelenggaraan kepemerintahan yang baik (good governance) yang melibatkan partisipasi aktif dan seimbang antara pemerintah, swasta, dan masyarakat. Dengan demikian, pembangunan berkelanjutan tidak saja terkait dengan isu-isu lingkungan, tetapi juga isu demokrasi, hak asasi manusia dan isu lain yang lebih luas. Pemasaran pariwisata yang bertanggungjawab (responsible tourism marketing) dalam industri pariwisata merupakan penjabaran dari konsep pengembangan kepariwisataan berkelanjutan (sustainable tourism development), khususnya terkait dengan aspek-aspek dalam pemasaran pariwisata. Pemasaran yang bertanggungjawab secara umum juga dikenal dengan istilah green marketing (Ottman, 1993) atau environmental marketing (Coddington, 1993). Kedua konsep tersebut masih relevan dalam pengembangan pemasaran pariwisata yang bertanggungjawab.

Kebijakan pengembangan pariwisata di Kabupaten Pemalang mencakup aspek kebijakan pengembangan perwilayahan, pengembangan produk pariwisata, pasar dan pemasaran, kelembagaan, sumberdaya manusia, dan investasi. Sementara perumusan strategi pengembangan kepariwisataan untuk Kabupaten Pemalang secara umum diarahkan mengikuti pola $5 \mathrm{C}$ strategi, yaitu:

- Core Strategy, yakni strategi dengan menyebarluaskan konsentrasi perkembangan pariwisata;

- Consequency Strategy, yakni strategi melalui pengembangan pusat primer baru bagi pertumbuhan pariwisata Kabupaten Pemalang;

- Customer Strategy, yakni strategi menciptakan iklim yang kondusif bagi pelaku usaha pariwisata, maupun wisatawan.

- Control Strategy, yakni strategi dengan membatasi pengembangan pariwisata untuk meningkatkan kualitas lingkungan; dan

- Culture Strategy, yakni strategi berupa peningkatan kesadaran dan perilaku masyarakat terhadap pariwisata dan konservasi lingkungan.

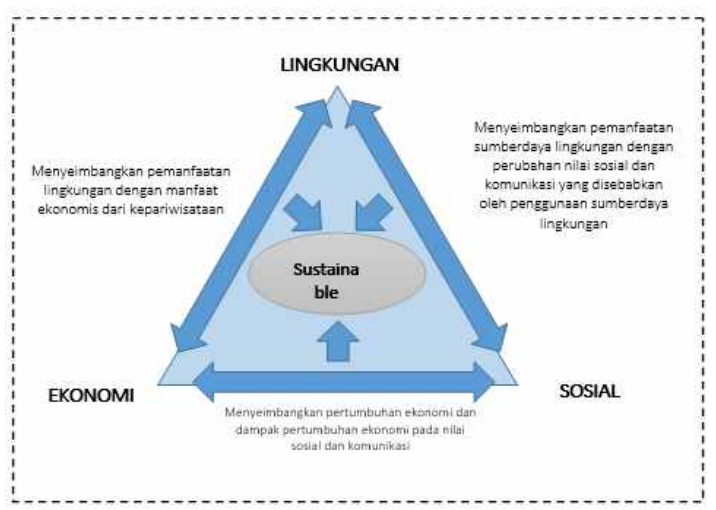

Gambar 2. Sustainable Tourism yang Dicapai Melalui Penyeimbangan Aspek Lingkungan, Ekonomi, dan Sosial (Diadaptasi dari Wray, 2010)

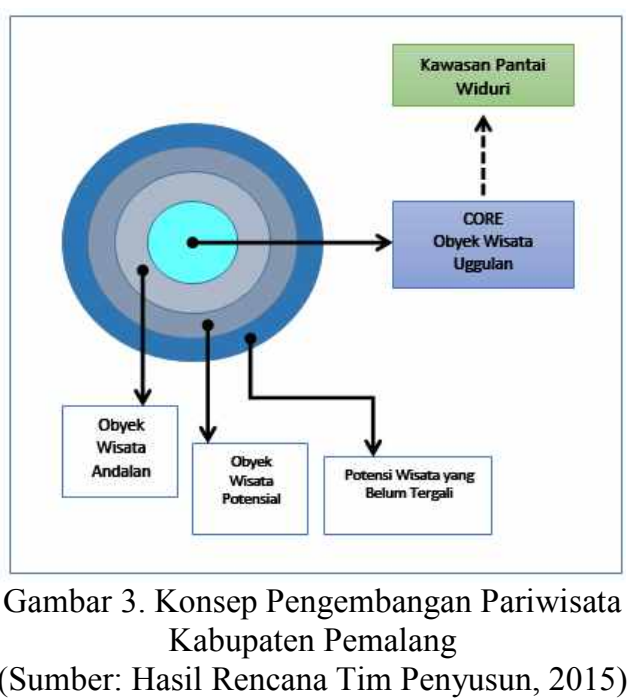




\section{Kesimpulan}

Kabupaten Pemalang memiliki Potensi Wisata yang cukup tinggi. Dalam perencanaan kepariwisataan di Kabupaten Pemalang, perlu adanya kebijakan dari Pemerintah terkait Zoning dan Tata Ruang sehingga dalam pelaksanaannya nanti Pembangunan Pariwisata tetap memperhatikan manfaat dari segi ekonomi, sosial, dan budaya. Kebijakan Pemerintah juga harus mendukung pemeliharaan Kekayaan Budaya, lingkungan alam, dan peninggalan sejarah yang ada di Kabupaten Pemalang. Pengembangan Pariwisata bertujuan untuk mendorong perekonomian masyarakat setempat dan menjadi pemicu dalam membangun masyarakat yang mandiri, tanggap terhadap permasalahan lingkungan yang terjadi di sekitar mereka, inovatif, dan memiliki semangat gotong royong dalam membangun dan memlihara lingkungan alam, sosial, dan budaya mereka. Rumusan ini diharapkan dapat mendukung pembangunan berkelanjutan melalui pengembangan pariwisata yang memerhatikan aspek ekonomi, sosial, dan budaya sehingga pengembangan pariwisata ini juga mendorong pertumbuhan ekonomi dalam perspektif jangka panjang di Kabupaten Pemalang.

\section{Acknowledgements}

Terimakasih kami ucapkan kepada semua pihak yang membantu terselesaikannya penelitian ini. Khususnya adalah Jajaran staff Dinas Pariwisata Kabupaten Pemalang serta para pegiat wisata dari berbagai daerah di Kabupaten Pemalang yang telah memberikan bantuan, kerjasama, dan informasi yang dibutuhkan dalam menyelesaikan Penelitian ini.

\section{Daftar Pustaka}

Ali Hasan.2014. Green Tourism Jurnal Media Wisata, Volume 12, No.1, Mei 2014

Dowling, R. K. 2010. Tourism's Emerging Global Interaction. Journal of the Geography Teachers' Association . 38 (2): pp 19- 23.

Dowling, R.K. 2010. Emerging tourism: Sustainable geo-resources for leisure and recreation.

Fennell, D.A. 2010. A Content Analysis of Ecotourism. Current Issues in Tourism, 4(5) pp 403

Journal of Tourism.10 (1): pp 209-220. Dowling, R.K. and Fennell, D.A. 2010. The Context of Tourism Policy and Planning. CAB International Journal. pp 1-20

Rulyanti Susi Wardhani, Devi Valeria. 2016. Jurnal Ilmiah Ekonomi Global Masa Kini Volume 7 No.01 Juli 2016

Weaver, D. 2012. Ecotourism. Australia : John Wiley \& Sons. p 15 